\title{
Aikuiskasvatus vastakkain itsensä kanssa
}

Aina 1960-luvulle asti aikuiskasvatuksella tarkoitettiin lähinnä kansanopistojen, kansalais- ja työväenopistojen sekä kansalaisjärjestöjen toteuttamaa ja valtion resurssoimaa vapaata sivistystyötä. Tällä hetkellä järjestelmä tavoittaa periaatteessa jokaisen aikuisen suomalaisen. Sen piiriin hakeutuukin vapaaehtoisesti joka vuosi noin miljoona aikuisopiskelijaa.

1960-luvun loppupuolella ammatillinen aikuiskoulutus alkoi vauhdilla lisääntyä. Jo muutaman vuoden kuluttua valtio resurssoi täydennys-, jatko- ja uudelleenkoulutusta sekä työllisyyskoulutusta moninkertaisesti vapaaseen sivistystyöhön verrattuna. 1980-luvulla, aikuiskoulutuksen kehittämisen vuosikymmenellä vapaa sivistystyö on jäämässä yhä selvemmin ammatillisen aikuiskoulutuksen jalkoihin. Päämääränä on ollut luoda suuri ja mahtava aikuiskoulutuksen kokonaisjärjestelmä. Kehittämissuunnitelmat on tehty korostetusti ammatillisen aikuiskoulutuksen näkökulmasta. Niinpä valtion kansansivistyslautakunta on lakkautettu ja tilalle asetetaan aikuiskoulutuksen neuvottelukunta, jossa on "tasapuolisesti" edustettuna niin ammatillinen kuin yleissivistäväkin aikuiskoulutus. Samanaikaisesti on kaavailtu aikuiskoulutuksen mitoitusperusteita, joissa vapaan sivistystyönkin resurssointi rinnastetaan oppivelvollisuus- ja velvoiteperusteiseen koulutukseen.

Mutta ovatko 1960-luvun koulutusoptimismiin, jatkuvan taloudellisen kasvun odotuksiin ja tieteellistekniseen kehitysuskoon perustuvat kokonaissuunnitelmamallit sittenkään oikeita?

\section{Aikuiskasvatuksen dualismi}

Humanisti on yleensä saanut väistyä tuotantoteknologiaan perustuvien koulutusratkaisujen tieltä. Tämä on ollut yleinen kehityssuunta koko koulutusjärjestelmää ajatellen. Aikuiskasvatuksessakin asettuu vastakkain yleissivistävä ja ammatillinen aikuiskoulutus - mutta mistä lähtökohdista?

Aikuiskasvatuksen dualismin perusteli alan teoreetikko ja ideologi Zachris Castren 1920luvulla. Hänen mukaansa kansansivistystyöhön ei voinut kuulua ammattisivistys. Sivistystyön sisällön hän määritteli suhteessa liberalistiseen oikeuskäsitykseen ja poliittiseen demokratiaan. Siten vapaan kansansivistystyön sisällöksi tuli kansalaiskasvatus, johon kuuluu kansalaiselämässä tarvittavien tietojen ja taitojen opiskelu mutta myös syvä humanistinen perusvire - hyväksi ihmiseksi kasvaminen.

Kaksijakoisuus leimaa myös aikuiskasvatuksen pedagogiikkaa. Raja lapsipedagogiikkaan on jyrkkä. Castrenin mukaan vain aikuiset kykenevät yhteiskunnalliseen oppimiseen, val-, tiollisten ja taloudellisten aineiden hallintaan. Nykyiset kognitiiviseen psykologiaan perustuvat ja monet muut oppimisteoriat eivät kuitenkaan vedä jyrkkää rajaa lasten ja aikuisten välille. Jokainen kantaa mukanaan lapsuusajan oppimiskokemusta. Kyky oppimiseen luodaan jo lapsena ja nuorena. Aikuispedagogiikka on myös korostetun yksilökeskeistä. Vaikka sosiaalisen taustan ja yhteisöarvojen merkitys tunnustetaankin, on sivistystyön yhteisökasvatus antanut odottaa itseään. Pikemminkin yk- 
silö on irroitettu taustastaan kuin kasvatettu yhteisön jäsenenä.

Castren veti sivistystyön vapauden rajaa valtion suuntaan. Valtion tulee rahoittaa sivistystyötä mutta taata sille toimintavapaus, autonomia. Näin yksilö on vapaa valitsemaan sivistykseksi määritellyn tieto-taitojoukon sisällöstä. Mutta nämä sisällöt määräytyvät hänen ulkopuoleltaan, eräänlaisen yleisen tarpeen ja edun perustalta. Vapaan sivistystyön subjektiksi nousee, ei yksilö vaan valtio.

\section{Sivistystyön poliittisuus}

Alkuperäinen liberalistinen kansanvalistus nojasi suuriin valistusaatteisiin; vapauden, veljeyden ja tasa-arvoisuuden periaatteisiin, uskoon ihmisen järkeen ja kykyyn ratkaista yhteiskunnan ongelmat tieteen ja edistyksen avulla. Kansallisuusaatteen läpitunkema valistustyö oli tärkeimpiä henkisiä muutostekijöitä 1800-luvun sääty-yhteiskunnan kumoamisesta. Se oli syvästi poliittista ja vallankumouksellista.

Kansallisvaltion perustamisen myötä kansansivistystyö sai apologeettisen luonteen, laillista yhteiskuntajärjestystä puolustavan ja luokkavastakohtaisuuksia tasoittavan merkityksen. Sen tarkoituksenmukaisuus ja yhteiskunnan tuki perusteltiin vuosikymmeniä yleissivistävien kansalaistietojen ja -taitojen tarpeella.

Kansalaiskasvatus siirtyi kuitenkin vähitellen varsinaiselle koulujärjestelmälle. Sivistystyön instituutio alkoi muuntua ja ohjautua markkinamekanismin mukaan: henkisten ja käytännöllisten harrastusten tavarataloista tarjotaan jokaiselle kysyvälle jotakin vapaa-ajan kulutukseksi. Alkuperäinen poliittisuus on muuttunut valtiolliseksi neutraalisuudeksi; värittömyydeksi, hajuttomuudeksi ja mauttomuudeksi ainakin yhteiskunnallisten aineiden osalta.

\section{Koulutuksen marginaaliorganisaatio?}

Huolimatta vahvasta institutionaalisesta asemasta vapaa sivistystyö ei ole kyennyt vastaamaan koulutusteknologian haasteeseen. Perinteisen argumentaation tylsyessä on sivistystyöhön alettu suhtautua valtion taholta koulutuksen marginaaliorganisaationa, jolla ei ole itsenäistä sivistystehtävää. Varoittava esimerkki arvostuksesta löytyy hyvinvointivaltio Norjasta, jossa sivistystyön valtionosuus on laskenut seurauksella, että henkilöstön määrä on pudotettu puoleen verrattuna Høyre-hallitusta edeltäneeseen aikaan. Vastaavan mahdollisuuden antaa Suomessa valtionvarainministeriön kaavailema suoriteperusteinen valtionosuusjärjestelmä, joka perustuu yhtäällä opetustuntien ja toisaalla osallistujien määrään. Vapaaehtoiseen osallistumiseen perustuvaa sivistystyötä on kuitenkin kyseenalaista mitoittaa muun koulutuksen tapaan. Lisäksi määrällinen suoritekriteeri voisi johtaa tunti- ja osallistujamäärien keinotekoiseen lisäämiseen. Opetuksen suunnittelua ohjaisivat helposti muodikkaat ja suositut aihevalinnat sekä "tähtiluennoitsijat" pitkäjänteisen laadullisen kehittämisen kustannuksella. Valtionvarainministeriölle järjestelmä tarjoaa 'kustannussäästöruuvin", koska se viime kädessä määrittäisi suoritteen hinnan ja perustaisi aina arvionsa aikaisempien vuosien määrälliseen kehitykseen.

\section{Voiko sivistystyö radikalisoitua?}

Kestävintä vapaassa sivistystyössä on ollut sen kyky toimia liberalismin perusajatuksen mukaisesti - sosiaalisen nousun väylänä. Moni koulutusjärjestelmän ulkopuolelle jäänyt on sen kautta saanut mahdollisuutensa. Kuitenkin koulutuksellinen hyväosaisuus on kertautunut: opiskelemaan oppineet ovat opiskelleet ja vähäosaiset ovat karsineet itse itsensä sivistystyön piiristä.

Koulutus ei enää tarjoa itsestäänselvää sosiaalista nousua vaan jopa työttömyyden. Samanaikaisesti automaatioteknologia vanhentaa työelämässä mukanaolevien koulutuksen. Toisaalta aineellinenkaan hyvinvointi ei näytä takaavan ihmisten tyytyväisyyttä. Henkinen kokeminen, sosiaalinen ja esteettinen eläytyminen ohjautuu yhä enemmän vapaa-ajan kulutusmarkkinoiden ehdoin. Monet kääntävät systeemille selkänsä vetäytyen yksityisyyteen, toisinajatteluun tai keinotekoisten materiaalisten ja psyykkisten kiihokkeiden varaan. Hyvinvointi-ihminen vieraantuu, liberalistisen ideologian merkitys ohenee.

Henkisen vapauden kokemus on luonteeltaan poliittista: kykyä päättää omista ja yhteisistä asioista. Mutta se ei ole kahden - valtion ja kansalaisen - kauppa. Väliin asettuu yhteisöjen taso, joka voi ehkäistä vieraantumista. Yhteiskunnan kehittyminen näyttäytyy monisubjektisena autonomisten yhteisöjen vuorovaikutuksena. Näin vaatimukseksi asettuu yhden subjektin, valtion kautta pakotetusta kokonais- ja alamaisajattelusta luopuminen.

Yhteiskunnan consensus asettuu toiseen va- 
loon; ei vain vahvojen intressiryhmien yksimielisyytenä vaan myös dialogina yhteiskunnallisten vähemmistöjen ja muutosvoimien kanssa. Kaikkia sosiaalisia instituutioita leikkaavat talouden, politiikan, hallinnon, ekologian ja ihmissuhteiden ristiriidat ovat ilmausta murtaa valtiollisen consensuspolitiikan betoni, joka raskaana lepää ihmisten autonomiapyrkimysten yllä. Koko arvojärjestelmämme on muutoksessa. Yhteiskunnallinen muutos on ennen kaikkea sivistyskysymys.

Ilman tiettyä radikalismia vapaa sivistystyö jää vapaa-ajan laitokseksi, jossa harrastetaan mukavia harrasteita ja yhteiskunnallista terapiaa sekä opitaan muuten hyödyllisiä asioita — hyvä niinkin mutta kovin loistava tulevai- suuskuva se ei ole.

Aikuisen oikeus oppimiseen on oikeutta vaikuttaa oppimisen sisältöön ja tapaan. Tästä näkökulmasta on samantekevää, oppiiko hän yleis- vai ammattisivistäviä aineita. Oppimisen välttämättömyyden ja mielekkyyden määrittää itse todellisuus, sen sosiaaliset ja taloudelliset realiteetit. Aikuinen on tekemisensä subjekti, jota ohjaavat henkilökohtiset valinnat ja toiminta. Olennaista järjestelmätasolla on vapaan sivistystyön toimintaperiaate. Säilyykö osallistuminen vapaaehtoisella perustalla? Onko poliittinen yhteiskuntamme siinä määrin sivistysvaltio, että se ohjaa sivistystyöhön riittävästi materiaalisia edellytyksiä? Henkiset resurssit ovat sivistystyön itsensä varassa. 